\title{
In honor of Philippe Garrigues
}

\author{
Stephen A. Wise ${ }^{1}$
}

Published online: 5 September 2019

(C) This is a U.S. government work and not under copyright protection in the U.S.; foreign copyright protection may apply 2019

It is a pleasure to write this editorial honoring Phillippe Garrigues at the end of his service as an Editor for Analytical and Bioanalytical Chemistry $(A B C)$. Philippe was one of the original six Editors of $A B C$ when the journal was founded in 2002 as a merger of several European analytical chemistry journals. He also represented the French Chemical Society (Société Francaise de Chime, SFC), one of the co-owner societies of the journal, at the co-owners' meetings until 2017.

Philippe received his education as a chemical engineer at the Louis Pasteur University in Strasbourg, and then he moved to the University of Bordeaux where he received a Ph.D. in Environmental Chemistry (1981) and Docteur d'État (DrE) (1985). During his professional career as a research director at the French National Center for Scientific Research (Centre National de la Recherche Scientifique, CNRS) at the University of Bordeaux, he held numerous leadership roles. In 1997, he was the cofounder of the Laboratory of Physico and Toxico Chemistry of Natural Systems, a laboratory focusing on environmental chemistry and toxicology, and he remained in this position until 2005 when he became the Director of the CNRS Research Center in Molecular Chemistry (2005-2006). He then served as the CNRS Director of the Institute of Molecular Sciences (2007-2015). He retired from CNRS in May 2019.

Not only have I had the privilege of working with Philippe as an editor colleague since the founding of $A B C$, but my association with him goes back nearly 40 years. During the early 1980s, Philippe published several landmark papers, which caught my attention, that focused on the identification of polycyclic aromatic hydrocarbons (PAHs) and alkylsubstituted PAHs and their use to differentiate pyrolytic or petrogenic origin [1-3]. Philippe and I met in the early 1980s when we both attended the International Symposium

Stephen A. Wise

stephen.wise@nih.gov

1 Office of Dietary Supplements, National Institutes of Health, 6100 Executive Blvd., Bethesda, MD 20892-7517, USA on Polycyclic Aromatic Compounds in Columbus, Ohio. Philippe's research focused on using low-temperature fluorescence spectroscopy (Shpol'skii) to identify polycyclic aromatic compounds (PACs), particularly PAHs in samples of environmental and geochemical interest. Because of our mutual enthusiasm for PAHs, we quickly established a collaboration, visited each other's laboratories numerous times, published several papers together [e.g., 4-6], and became close scientific and personal friends.

Philippe's research interests have always been multidisciplinary spanning analytical chemistry, environmental chemistry, geochemistry, and toxicology. He performed most of his research using molecular spectrometric and chromatographic techniques. Philippe's top eight most-cited papers, with over 3000 citations, all involve the determination of PAHs in marine sediments and tissues in various studies. In addition to research with PAHs, he has also been involved with analytical methods development and environmental monitoring applications for many classes of environmental contaminants including polychlorinated biphenyls (PCBs), chlorinated pesticides, organophosphorus and organonitrogen pesticides, butyltins, and dioxins.

Philippe has made significant contributions in areas of analytical chemistry, organic geochemistry, environmental chemistry, and ecotoxicity, including the following:

- Development and analytical use of low-temperature fluorescence (Shpol'skii) spectroscopy to identify PAHs and alkyl-PAHs

- Development of GC and LC methods for isolation, separation, and identification of PACs

- Correlation of structure and chromatographic (GC and LC) behavior of PACs (e.g., phenanthrenes, chrysenes, perylenes, and dibenzothiophenes)

- Use of PAH and alkyl-PAH distributions as indicators of origin and maturity in recent and ancient sediments

- Development of extraction techniques for organic contaminants using microwave fields

- Investigations of relationships between levels of contamination of aromatics and PCBs in the aquatic marine and 
Fig. 1 The "Barcelona Five" (from left to right: Philippe Garrigues, Jan Andersson, Jürgen Jacob, Steve Wise, and Karlheinz Ballschmiter) in the cellar restaurant "Los Caracoles" in Barcelona, Spain, in 1988 eating snails and discussing their mutual interests in PACs

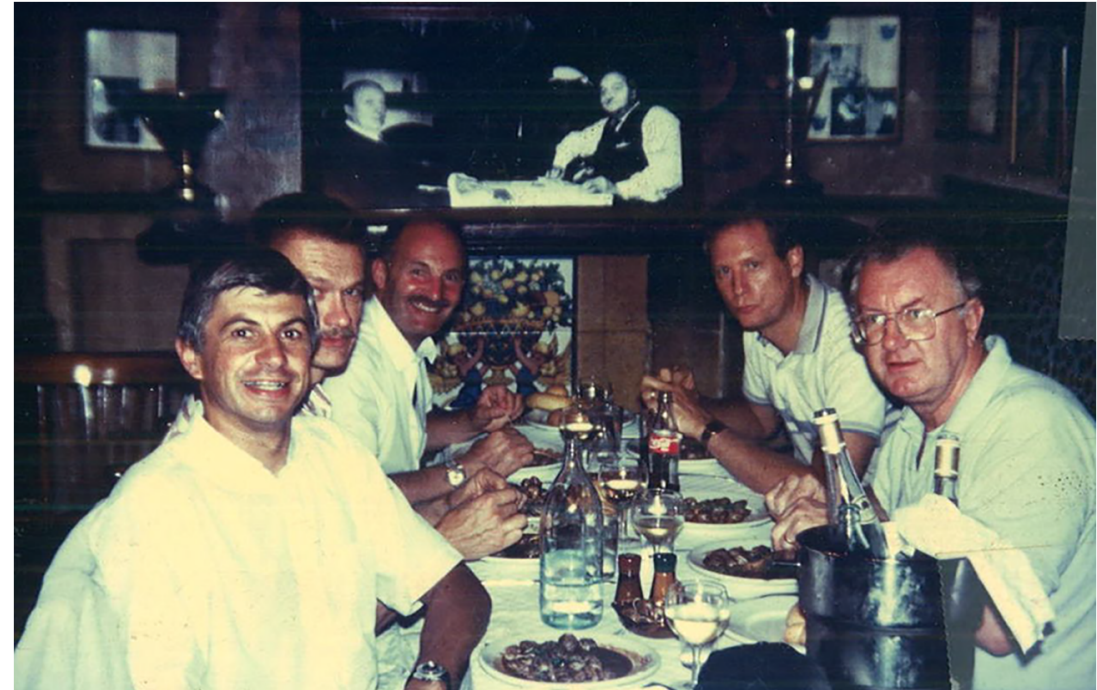

freshwater environments and biochemical indices relating to biotransformation of these compounds by bivalves

- Use of an integrated multi-contaminant and multibiomarker approach in field studies

Philippe has been extremely active in professional societies with positions of leadership including the French Society of Chemistry, Society of Environmental Toxicological and Chemistry (SETAC-Europe) (Executive Committee), the International Society of Polycyclic Aromatic Compounds (ISPAC) (serving as President in 1997-1999, 2001-2003, and 2011-2013), the Division for "Chemistry in the Environment" of European Chemistry Society (EuCheMS) (President, 2003-2008), European Association for Chemical and Molecular Sciences (EuCheMS) as the representative of SCF (since 1998) for the Division of "Chemistry and the Environment" (DCE) (Chair, 2002-2008), the Rovaltain Scientific Cooperation Foundation for Ecotoxicology and Environmental Toxicology (President, 2003-2008), and School of European Analytical Sciences (EESA) (President, 2005-2008).

Philippe has organized and coordinated major international scientific programs including the European Commission (EC) projects on "Biological Markers of Environmental Contamination in Marine Ecosystems" (BIOMAR) (1994-1998), which was succeeded by "Biological Effects of Environmental Pollution in Marine Coastal Ecosystems" (BEEP) (2001-2004). These two EC programs involved over 30 European laboratories and resulted in 105 theses and 550 publications.

Philippe has been a prolific organizer of scientific symposia, generally held in his beautiful home city of Bordeaux. He organized and hosted the following symposia: ISPAC in 1991, 1999, and 2015; SETAC-Europe
(1998); International Conference on Chemistry and the Environment (FECS) (2004); International Symposium on Pollutants in Marine Organisms (2009); Euroanalysis (2015); and International Symposium on Life Cycle Management (2015), as well as numerous workshops on various specialty topics or European Commission projects. I have had the good fortune to experience a number of these symposia, which always included wonderful excursions into the countryside to visit vineyards ending with a fine dinner at a beautiful chateau. Philippe is always an enthusiastic and gracious host for both large groups of participants and one-on-one interactions. I fondly remember a road trip from Bordeaux to Barcelona with Philippe and another colleague to attend a meeting in 1988. When he and the colleague picked me up at the Bordeaux train station in his old beat up car with little legroom and no air conditioning, they led me to believe that this was the vehicle that I would be riding in for the $650-\mathrm{km}$ drive to Barcelona. Fortunately, it was not. $\mathrm{He}$ always enjoys a good laugh.

In addition to serving as an $A B C$ Editor for the past 18 years, Philippe has also been the Editor-in-Chief for the International Journal of Polycyclic Aromatic Compounds since 1998 and Environmental Science and Pollution Research since 2011. He plans to continue in these Editorin-Chief roles in the foreseeable future.

Philippe's professional involvement in environmental chemistry stems from his love for the ocean and the rivers near his home in Bordeaux. During his youth, he spent his summers at the family home on Arcachon Bay $(70 \mathrm{~km}$ from Bordeaux) enjoying boating, fishing, diving, and surfing. He has traveled the world in search of good surf and exotic diving opportunities. He regularly surfs on the Gironde River when the tides are just right to produce waves, which is also the site of his most highly cited study of PAHs in the environment [7]! 


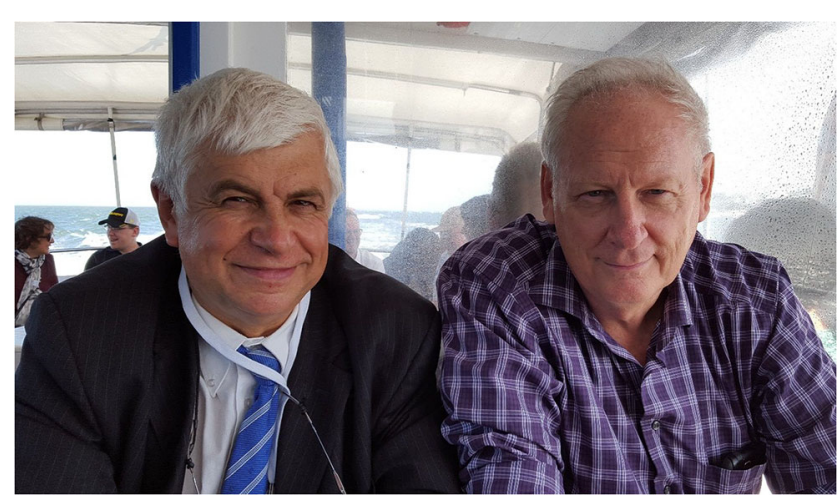

Fig. 2 Philippe Garrigues and Steve Wise on a boat in Arcachon Bay in September 2015 on an excursion during a symposium organized by Philippe

We will miss Philippe as an $A B C$ editor. He has served the journal and the SCF well in promoting analytical and environmental chemistry throughout France and Europe. Knowing Philippe's enthusiasm for these topics, I am sure that he will continue to be involved within these communities for some years to come. However, I also know that he plans to spend more time in his beloved Arcachon Bay, building two new homes on the site of his family home, so that he (and his guests) can enjoy more boating and fishing (and of course, cooking and eating the fish) and riding the waves on the Gironde. We wish Philippe the best in his new, flexible, relaxed state, and we look forward to sharing the view over Arcachon Bay with him sometime in the future (Figs. 1 and 2).

\section{References}

1. Garrigues P, Ewald M. Identification of monomethylated polycyclic aromatic hydrocarbons in crude oils by liquid chromatography and high-resolution Shpol'skii effect fluorescence spectrometry. Anal Chem. 1983;55(13):2155-9.

2. Garrigues P, Devazelhes R, Ewald M, Joussotdubien J, Schmitter $\mathrm{JM}$, Guiochon G. Identification of triaromatic azaarenes in crude oils by high-resolution spectrofluorimetry in Shpol'skii matrices. Anal Chem. 1983;55(1):138-40.

3. Garrigues P, Bourgeois G, Veyres A, Rima J, Lamotte M, Ewald M. Comparison of methylphenanthrene isomer detection in petroleum extracts by gas-chromatography mass spectrometry and Shpol'skii luminescence spectrometry. Anal Chem. 1985;57(6):1068-70.

4. Garrigues P, Marniesse MP, Wise SA, Bellocq J, Ewald M. Identification of mutagenic methylbenz $[a]$ anthracene and methylchrysene isomers in natural samples by liquid chromatography and Shpol'skii spectrometry. Anal Chem. 1987;59(13):1695700 .

5. Garrigues P, Bellocq J, Wise SA. Determination of methylbenzo $[a]$ pyrene isomers in a coal-tar reference material using liquid chromatography and Shpol'skii spectrometry. Fresenius J Anal Chem. 1990;336(2):106-10.

6. Garrigues P, Budzinski H, Manitz MP, Wise SA. Pyrolytic and petrogenic inputs in recent sediments - a definitive signature through phenanthrene and chrysene compound distribution. Polycycl Aromat Compd. 1995;7(4):275-84.

7. Budzinski H, Jones I, Bellocq J, Pierard C, Garrigues P. Evaluation of sediment contamination by polycyclic aromatic hydrocarbons in the Gironde estuary. Mar Chem. 1997;58(1-2):85-97.

Publisher's note Springer Nature remains neutral with regard to jurisdictional claims in published maps and institutional affiliations. 